\title{
Getting Out of a Foreign Policy Impasse: The Decolonisation of Angola and Mozambique
}

On 25 April 1974, a military coup d'état in Portugal, supported by large parts of the population, changed the dynamics of the independence wars in Southern Africa. Almost without bloodshed, the Movimento das Forças Armadas (Armed Forces Movement, MFA), constituted mainly of junior officers, toppled the Estado Novo regime. Although the coup came as a surprise to both the Portuguese leaders and international observers, growing discontent within the military had been evident for some time. At its root were the independence wars in Africa. After more than a decade of war, Portuguese defeat in Guinea-Bissau, whose independence the liberation movement PAIGC had unilaterally declared in September 1973, became increasingly likely. In February 1974, General António de Spínola, former Portuguese commander-in-chief in Guinea-Bissau, published a book in which he called for reforms in Portugal. He also argued that the solution to the wars in Africa had to be political, not military. The book quickly became a bestseller and undermined the position of Prime Minister Marcello Caetano. The junior career officers who comprised the majority of the MFA were motivated mainly by their perceived loss of status after a series of reforms improved the situation of conscripted officers. Yet, their dissent was also an expression of wide-ranging dissatisfaction with the organisational problems of the Portuguese army linked to the extensive troop demands of the African wars. ${ }^{1}$ Faced with this discontent, the Caetano regime failed to act decisively. There was next to no resistance when the MFA took control of Lisbon on 25 April 1974. General Spínola was chosen to head the Junta of National Salvation that assumed power in Portugal and later became the first provisional president. The secret police and censorship were abolished, political prisoners liberated, the army reorganised and civil governors dismissed. The MFA's programme was deliberately vague on the question of the future of Portugal's African colonies, in order to appeal to as great a number of people as possible. Its final version contained no commitment to the principle of selfdetermination. Instead, it argued that a negotiated solution was needed to the

1 Kenneth Maxwell, The Making of Portuguese Democracy, Cambridge: Cambridge University Press, 1995, pp. 30-38; MacQueen, The Decolonization of Portuguese Africa, pp. 68-77.

(C) SABINA WIDMER, 2021 | DOI:10.1163/9789004469617_010

This is an open access chapter distributed under the terms of the CC BY-NC-ND 4.0 licensense. widmer - 9789004469617 
independence wars, that an open, national debate about the overseas problem should take place, and that steps should be taken to adopt an overseas policy that would lead to peace. ${ }^{2}$

The Carnation Revolution introduced a period of profound political, economic, and social transformation in Portugal, where no less than six provisional governments followed in rapid succession before a democratically elected president took office in June 1976, at the head of a constitutional democracy. In Africa, the fall of the Estado Novo regime marked the beginning of the decolonisation of Angola, Mozambique, Guinea-Bissau, Cape Verde, and São Tomé e Príncipe. Unwilling to continue the financial and military commitment necessary to fight the liberation movements in the colonies, the new Portuguese authorities were, by July 1974, ready to negotiate the transfer of power. The approaching end of Portuguese colonial rule increased the pressure on the white minority regimes in Rhodesia and South Africa and intensified the liberation struggle in Southern Africa.

The period between early 1974 and mid-1975, when Mozambique became independent and the struggle between the Angolan liberation movements escalated into all-out war, with interventions from both sides of the global East-West conflict, was crucial for Switzerland's foreign policy in sub-Saharan Africa. In the first months after the Carnation Revolution, there was great uncertainty about the future of the Portuguese colonies. In Bern, Switzerland's role in Southern Africa was hotly debated. The Portuguese coup offered a way out of the impasse created by the Swiss government's selective interpretation of neutrality. As soon as Portugal's new leaders were willing to grant independence to the former colonies and the independence wars in Mozambique and Angola were drawing to a close, the need to make a trade-off between relations with the coloniser and the colonised disappeared. Like the US, France, the FRG, and the UK, the Swiss government strove to overcome its past association with the Portuguese colonial regime. To silence the ever-mounting national and international criticism of Switzerland's economic and financial role in Southern Africa, protect Swiss interests in Angola and Mozambique, and develop economic exchanges with the new states, Bern undertook great efforts to establish cordial relations with the Portuguese territories' future rulers, despite their Soviet ties. These efforts were also part of a general Swiss attempt to strengthen its relations with Third World governments in the context of the North-South conflict.

2 Maxwell, The Making of Portuguese Democracy, pp. 56-6o; MacQueen, The Decolonization of Portuguese Africa, pp. 79-87. 


\section{"The Coup in Portugal Has Set the Ball Rolling": Internal Debates on Switzerland's Southern Africa Policy}

Exactly one month after the Carnation Revolution, Swiss Ambassador Richard Pestalozzi, who was stationed in Kenya, reported how the political and military situation started to move after the Portuguese coup d'état. ${ }^{3}$ Although his words referred to events in Mozambique, they applied to the whole of Southern Africa. The anticipated withdrawal of the Portuguese colonial power strengthened the calls for national liberation in the region. Afro-Asian pressure on the Federal Council to take decisive action to prevent Swiss firms and banks from collaborating with and investing in the region continued to mount. In April 1974, the publicity given to numerous complaints to the UN about Swiss firms or individuals breaking the economic sanctions had reached the point that FPD leaders agreed to take steps to restrict the export of Swiss goods and capital to Rhodesia. ${ }^{4}$ In late May, the UN Unit on Apartheid (later Centre against Apartheid) published a critical report on Switzerland's relations with South Africa. Its author was Gilbert Rist, director of the Geneva-based Centre EuropeTiers Monde (Europe-Third World Centre, CEтіM), a member of the Swiss Anti-Apartheid Movement and member of the Advisory Commission on Switzerland's Relations with the UN. ${ }^{5}$ In late June, the OAU's Council of Ministers urged its member states "to blacklist those persons, companies and institutions in their countries which in pursuance of colonial and racial interest continue to have dealings or business with the illegal regime in southern Rhodesia". African leaders even considered using access to raw materials as leverage to force states to comply with the UN sanctions, as the OPEC states had done during the 1973 oil embargo. 6 Thus, behind the scenes, Switzerland's foreign policy in Southern Africa was the subject of intense debate in 1974.

3 PR no 4 by Richard Pestalozzi, Swiss ambassador in Kenya, "Die Lage in Malawi", 24.05.1974, p. 3, SFA E2300-O1\#1977/30\#59*.

4 SLR, memorandum, "Aktennotiz zum Vorbereitungsgespräch für die Sitzung vom 10. April 1974 mit den Vertretern des EVD", 08.04.1974, SFA E2001E-o1\#1987/78\#4773*; Claude Huguenin, DPA, memorandum, "Sanctions rhodésiennes: séance interdépartementale du 10 avril 1974", o6.o5.1974, SFA E7110\#1985/97\#1755*.

5 See the letter from René Keller, chief of the Dio, to the main federal offices and Swiss embassies in Africa and New York, "Beziehungen zwischen der Schweiz und Südafrika. UNO-Dokument”, 15.07.1974, SFA E2003A\#1988/15\#1508*.

6 Resolution CM/Res 347 (XXIII) of the OAU Council of Ministers' 23rd Ordinary Session from 6 to 11 June 1974, "Resolution on Sanctions against Rhodesia", https://au.int/sites/default/ files/decisions/9582-council_en_6_15_june_1974_council_ministers_twenty_third_ordinary _session.pdf (13 January 2021); telegram no 197 from Heinz Langenbacher, Swiss ambassador in Ethiopia, to the FPD, 27.06.1974, SFA E2O01E-01\#1987/78\#4329*. 
Despite the MFA programme's non-committal stance on self-determination in Portuguese Africa, it was evident to most Swiss observers that the Carnation Revolution would have far-reaching consequences for the colonies' future. In Bern, the view of the Swiss ambassador in Portugal, Jean-Louis Pahud, expressed in early May 1974, that any solution to the colonial problem other than the complete independence of Portugal's African colonies was unlikely, was widely shared. ${ }^{7}$ How much control the new Portuguese authorities would have over the decolonisation process, in particular over its timing, and what this would mean for Swiss interests and policies in Southern Africa, was less certain.

FPD leaders had no intention of getting mixed up in what Federal Councillor Pierre Graber considered to be a complex and potentially violent decolonisation process. In a meeting with the Foreign Policy Committee of the Council of States in late May 1974, he presented Southern Africa as one of the most alarming trouble spots worldwide. Failed peace negotiations due to factionalism in Portugal and Angola, a unilateral declaration of independence by white settlers in Mozambique, and a South African military intervention in Portuguese Africa to prevent the spread of African nationalism were some of the risks he outlined. From a global perspective, the presence of the US and the USSR in Southern Africa due to the region's strategic importance and natural resources, rendered the situation even more volatile. ${ }^{8}$ Referring to Switzerland's role in this context, Graber hinted that the intermediary of Swiss missionaries, who were known to have shown sympathy for the liberation movements, and the granting of humanitarian aid would help Switzerland protect its interests in Angola and Mozambique. ${ }^{9}$ Despite some concern that the political changes in Angola and Mozambique might have negative consequences for trade relations, ${ }^{10}$ the Swiss government intended to follow its old strategy for dealing with the decolonisation of former colonies: adopt a low profile, keep out of all conflicts, and later win over the future rulers with the offer of humanitarian and development aid. As yet, Bern made no special efforts to enter into contact with the liberation movements in Portuguese Africa in order to get on good terms with these territories' probable future elites. ${ }^{11}$

PR no 9 by Jean-Louis Pahud, Swiss ambassador in Portugal, "Le problème de l'Outre-mer portugais après le coup d'Etat du 25 avril”, 10.05.1974, p. 2, SFA E230o-01\#1977/3O\#49*. Statement of Pierre Graber, Federal Councillor and head of the FPD, in the minutes of the meeting of the Foreign Policy Committee of the Council of States on 27 May 1974, 31.05.1974, pp. 13-14, SFA E1050.12\#1995/512\#8*.

9 Ibid., p. 18.

10 Letter from Ernst Henri Léchot, responsible for relations with Portugal within the Trade Division, to the Swiss consulates in Angola and Mozambique, "Mozambique und Angola - Einfuhrregime", 05.06.1974, SFA E7110\#1985/97\#1259*. 
For Swiss citizens living in the Portuguese colonies, the consequences of the regime change in Portugal were immediate. In Mozambique, the Portuguese Governor-General was recalled, censorship abolished and the secret services (PIDE/DGS) reorganised. Nevertheless, Swiss consul Louis Chaney reported a few days after the Carnation Revolution that daily life as well as the war between FRELIMO and the Portuguese army continued almost unchanged. The traders and planters that comprised almost half of the 200 Swiss residents in Mozambique expressed some fear about their long-term future in Mozambique. The missionaries, who made up the other half, welcomed the political changes. ${ }^{12}$ In Angola, several liberation movements and political parties started to compete for power, rendering the general insecurity even greater than in Mozambique. ${ }^{13}$ Swiss solidarity movements that had protested for years against Portuguese colonialism rejoiced at the new freedoms enjoyed in Portugal after the coup. However, in a letter accompanying a petition to the Federal Council to recognise Guinea-Bissau that had obtained about 5,000 signatures, a solidarity group, the Collectif Europe-Afrique, insisted on the continuing need to press for the MFA to commit to decolonisation. After all, "the numerous imperialist interests, both strategic and economic, that developed and made profits under the Portuguese regime might well support a neo-colonialist solution."14 The activists therefore demanded, in vain, that the Swiss authorities should support the liberation movements' quest for complete independence.

The Swiss government's cautious attitude during the first months following the Portuguese coup and their confidence in their ability to buy the goodwill of Angola's and Mozambique's future rulers may seem surprising. After all, Swiss foreign policymakers were well aware of the damage caused to their image by their close relations with the white minority regimes in Southern Africa. In late May 1974, a member of the Swiss Anti-Apartheid Movement who had recently travelled to Tanzania and Mozambique warned the DPA that Switzerland's

Letter from Walter Jaeggi, Swiss ambassador in Denmark, to the DPA, "Besuch des MPLA (Angola)-Leiters Agostinho NETo in Kopenhagen und sozialdemokratische Beziehungen Dänemark-Portugal", o8.05.1974, SFA E2001E-o1\#1987/78\#4650*.

Letter from Louis Chaney, Swiss consul in Mozambique, to the DPA, 29.04.1974, p. 1, SFA E20o1E-o1\#1987/78\#4651*; letter from Chaney to the DPA, "Situation au Mozambique (dès le 1er mai) sous le regime de la Junta de Salut National”, o6.05.1974, pp. 2-3, ibid. See also the letter from missionary Marcel Vonnez to Georges Andrié, DM, 21.06.1974, ADM 3056G. I am indebted to the late Patrick Harries for drawing my attention to the Vonnez correspondence.

13 Letter from Roland Gottraux, Swiss honorary consul in Angola, to the Swiss Embassy in Lisbon, 26.05.1974, SFA E2200.54-O3\#1992/228\#252*.

14 Letter from the Collectif Europe-Afrique to the Federal Council, 29.05.1974, p. 2, SFA E2001E-o1\#1987/78\#3234*. 
“image was not very good among FRELIMO's leaders, who criticise its abstaining neutrality". ${ }^{15}$ His words echoed the disapproval of the Swiss authorities' selective interpretation of neutrality uttered by a FRELIMO representative during the international humanitarian law conference in Geneva in early $1974 .{ }^{16}$

Only four days after the events of 25 April, the deputy chief of the DIO, whose directorate was more attuned to the ramifications of the Third World's condemnation of Swiss neutrality than other FPD services, took up the FRELIMO member's criticism of Swiss partiality during the independence wars. He asked Swiss ambassadors in sub-Saharan Africa if the moment had come to grant humanitarian aid to the liberation movements in Portuguese Africa. ${ }^{17}$ The replies reveal that there was no agreement on strategy. Despite his misgivings about FRELIMO's Eastern bloc connections and violent strategies, Richard Pestalozzi reasoned that the quick granting of aid to the Portuguese colonies' future rulers might prevent Switzerland from being considered part of the "camp of the reactionaries and racists". ${ }^{18}$ His colleague in Ethiopia, Heinz Langenbacher, was more enthusiastic about support for the liberation movements. He even argued that the government should go further and limit Swiss investment in Southern Africa. ${ }^{19}$ However, the view that won the day in Bern was that of Lucien Mossaz in Tanzania, who argued that it was contrary to Switzerland's policy of neutrality to support dissident movements that were still engaged in armed conflict. ${ }^{20}$

In the light of Afro-Asian leaders' growing determination to bring white minority rule to an end, Pestalozzi and Langenbacher increased their calls for a new Swiss Southern Africa policy. Their demand for the restriction of the activities of Swiss firms and banks in this region placed them at one extreme of the split that divided the Swiss government and federal administration. Commenting on the minutes of the first interdepartmental meeting on Switzerland's

15 Statement by Pierre Bungener, President of the Swiss Anti-Apartheid Movement, cited in Claude Huguenin, memorandum, "Entrevue avec M. Bungener, Président du Mouvement Anti-Apartheid de Suisse, le 29.5.1974”, 31.05.1974, SFA E2001E-01\#1987/78\#4651*.

16 Cited in the letter from François Pictet, deputy chief of the Dio, to the Swiss embassies in Ethiopia and Tanzania and the Office of the Permanent Observer of Switzerland to the UN, "Possibilité d'une aide suisse en Afrique australe", 29.04.1974, pp. 1-2, SFA E2005A\#1985/101\#547*.

17 Ibid.

18 Letter from Richard Pestalozzi to the DIO, "Schweizerische Unterstützung der Befreiungsbewegungen im südlichen Afrika”, o6.o6.1974, p. 3, SFA E2001E-o1\#1987/78\#4651*.

19 Letter from Heinz Langenbacher to the DIo, "Hilfe für afrikanische Befreiungsbewegungen", 24.06.1974, p. 3, SFA E2200.185-O2\#1987/123\#42*.

20 Letter from Lucien Mossaz, Swiss ambassador in Tanzania, to the Dio, "Possibilité d'une aide suisse en Afrique australe", o8.05.1974, SFA E2OO3A\#1988/15\#573*. 
Rhodesia policy in early April 1974, Pestalozzi got the "impression of a retarding Trade Division and a pressing Political Department. It is the old question of whether trade interests precede political interests in the formation of Swiss foreign policy or vice versa." ${ }^{21}$ Indeed, in the frequent meetings taking place over the following months, the Trade Division resisted the FPD leaders' efforts to restrict Swiss exports to Rhodesia by trying to minimise the problem and gain time. ${ }^{22}$ Langenbacher saw it as his duty, as he wrote to the DIO in July 1974, to provide the necessary facts "that permit you to counterbalance the power of trade and industry, which, as I know from my time at the head office, maintain strong pressure on our Africa policy and frequently neglect long-term, general Swiss interests." 23

Faced with strong resistance from Swiss economic and financial circles, FPD officials were in a quandary. Their efforts to comply with African demands to curtail Switzerland's economic relations with Rhodesia were constantly thwarted. Similarly, the majority of the Federal Council refused to limit Swiss collaboration with South Africa. ${ }^{24}$ The decolonisation of Angola and Mozambique provided Swiss decision makers with a far less controversial opportunity to counterbalance their close relations with white minority regimes by supporting the leadership and populations of independent black African states. Thus, Switzerland's close political and economic relations with South Africa and Rhodesia continued to loom large over its foreign policy in the region.

What influence did Swiss-Portuguese relations have on Bern's foreign policy during the decolonisation of Angola and Mozambique? During the first few months after the MFA coup, the Swiss government was attentive to the position of the coloniser. FPD leaders waited for an official Portuguese commitment to decolonisation before seeking to contact the future rulers of Angola

21 Letter from Richard Pestalozzi to the DPA, “Sanktionen gegen Rhodesien”, 30.05.1974, p. 4, SFA E2200.185-02\#1987/123\#44*.

22 Claude Huguenin, memorandum, "Sanctions rhodésiennes. Discussion dans le bureau de M. l'Ambassadeur Rothenbühler le 29.4.1974", 30.04.1974, SFA E2001E-01\#1987/78\#4765*; see also Ross, Neutrality and International Sanctions, pp. 174-177.

23 Letter from Heinz Langenbacher to the Dio, "Beziehungen Schweiz - Südafrika; UNoDokument”, 29.07.1974, p. 2, SFA E2003A\#1988/15\#1508*.

24 In July 1974, for example, the Federal Council agreed to grant an ERG cover to ввС for deliveries to South Africa amounting to $\mathrm{CHF} 327$ million despite the opposition of the FPD, which feared that this deal might become public and damage Switzerland's image in Africa: Decree of the Federal Council, "Exportrisikogarantie an die Firma AG Brown Boveri \& Cie, Baden im Wert von 327 Mio. Franken für die Lieferung von drei Dampfturbinengruppen nach der Republik Südafrika", o9.07.1974, and the attached report from Pierre Graber to the Federal Council, "Afrique du Sud. Garantie contre le risque d'exportation", 24.06.1974, dodis.ch/40342. 
and Mozambique and taking steps to establish cordial relations with the soonto-be independent states. Once the Portuguese provisional government agreed to the independence of its former colonies, Bern was no longer bound by its solidarity with a fellow EFTA member. The major social, political, and economic transformations that followed the Carnation Revolution and continued until early $1976 \mathrm{kept}$ the different Portuguese transitional governments fully occupied. Consequently, the colonial power played a rather weak and passive role during the decolonisation of its African colonies. Switzerland and other Western and neutral states viewed developments in Portugal separately from those in Portuguese Africa.

Initially, they focused on the European theatre. Between 1974 and 1976, different political parties and sections of the Portuguese military and the population competed for the power to determine the country's orientation in the East-West conflict. The leaders of the Western bloc were preoccupied by the growing influence of left-wing officers of the MFA and of the Partido Comunista Português (Portuguese Communist Party, PCP), which participated in the Portuguese government. Blinded by 'a Cold War lens', Secretary of State Henry Kissinger focused on the Communist threat within nato. Fearing a domino effect in other European states, he aimed to exclude Portugal from sensitive NATO information and even considered covert operations in the Southern European state. In contrast, Western European governments and Social Democratic leaders in the UK, France, the FRG, Sweden, Norway, and the Netherlands supported the moderate forces in Portugal, especially the Partido Socialista (Socialist Party, PS). At a time when democratic transitions were also under way in Greece after the fall of the colonels' regime in July 1974 and in Spain after Franco's death in November 1975, they sought to bind Portugal politically and economically to Western Europe. ${ }^{25}$

25 On international reactions to the Portuguese Revolution, see David Castaño, "'A Practical Test in the Détente': International Support for the Socialist Party in the Portuguese Revolution (1974-1975)", Cold War History 15:1 (2015), pp. 1-26; Ana Mónica Fonseca, "The Federal Republic of Germany and the Portuguese Transition to Democracy (1974-1976)", Journal of European Integration History 15 (2009), pp. 35-56; Oscar Jose Martin Garcia, "The End of the Carnival': The UK and the Carnation Revolution in Portugal", Contemporary British History 29:2 (2015), pp. 199-221; Bernardino Gomes, Tiago Moreira de Sá, Carlucci vs. Kissinger. The US and the Portuguese Revolution, Lanham: Lexington Books, 2011; Mario del Pero, "A European Solution for a European Crisis. The International Implications of Portugal's Revolution" Journal of European Integration History 1 (2009), pp. 15-34; Mario del Pero, "Which Chile, Allende?' Henry Kissinger and the Portuguese Revolution", Cold War History 11:4 (2011), pp. 625-657; Pedro Aires Oliveira, "O Flanco Sul sob Tensão. A NATo e a Revolução Portuguesa, 1974-1975”, Relações Internacionais 21 (2013), pp. 61-78; Schneidman, Engaging Africa, pp. 139-185; Antonio Varsori, "Crisis and Stabilization in 
Up until mid-July 1974, Swiss diplomats in Washington had twice discussed the situation in Portugal with State Department officials. This attests to a more immediate preoccupation with the situation in Europe than with that in the African colonies. ${ }^{26}$ Nevertheless, Bern preferred to keep its distance from the ever-changing Portuguese governments, especially after the takeover by radical MFA officers close to the PCP, following a failed anti-Communist putsch in mid-March 1975. These officers immediately nationalised banks and insurance companies. At the same time, an increasingly assertive popular movement of farm labourers, industrial workers, and inhabitants of poor urban neighbourhoods occupied houses and agricultural estates, demanding better wages and living conditions. ${ }^{27}$ In early 1975, a number of Swiss business people were expelled from their workplaces, while workers committees occupied some Swiss-owned firms. ${ }^{28}$

In order to support moderate forces in Portugal, the FRG, France, and the US granted bilateral credit arrangements to Portugal amounting to CHF 73.6 million, CHF 17 million, and CHF 38.7 million, respectively. Both the EEC and EFTA agreed on the principle of aid to Portugal. In this context, the Swiss government found it increasingly difficult to dissociate itself from international attempts to stabilise the Portuguese economy. In early July 1975, the FPD and the FDEA underlined Switzerland's shared responsibility to prevent extremist forces from taking power in Portugal. ${ }^{29}$ Three months later, representatives of the Trade Division, the FPD, Switzerland's representation to EFTA, and the Vorort decided to respond positively to Portuguese requests for aid from EFTA. Thereby, they wished to avoid, both being the scapegoat if multilateral pro-

Southern Europe during the 1970s: Western Strategy, European Instruments", Journal of European Integration History 1 (2009), pp. 5-14; Tilo Wagner, "Portugal and the German Democratic Republic during the Carnation Revolution", Portuguese Journal of Social Science 7:1 (2008), pp. 37-47.

26 PR no 45 from the Swiss embassy in the US, "Portugal nach dem Militaerputsch, von Washington aus gesehen”, 24.05.1974, SFA E2300-O1\#1977/3O\#88*; PR no 62 from Felix Schnyder, Swiss ambassador in the US, "Portugal - Spanien, von Washington aus gesehen", 15.07.1974, ibid.

27 Maxwell, The Making of Portuguese Democracy, pp. 86-89; 108-112; 117-120;

28 Henri Cuennet, FPD, memorandum, "Protection des personnes et des intérêts suisses au Portugal", 12.06.1975, attached to the letter from Charles Müller, Deputy Chief of the DPA, to the Swiss embassy in Portugal, "Intérêts suisses au Portugal", 12.06.1975, SFA E2200.54O3\#1992/228\# 367 .

EPD and FDEA, proposal to the Federal Council, "Relations avec le Portugal", 04.07.1975, SFA E7OO1C\#1985/232\#522*. The credits of Deutschmark 70 million and US\$ 15 million have been converted to CHF using the exchange rates indicated in Officer, "Exchange Rates Between the United States Dollar and Forty-one Currencies". 
grammes should fail, and letting the Scandinavian governments enjoy the benefits of a successful action alone. ${ }^{30}$ Consequently, the Swiss delegation agreed during the EFTA Ministerial Meeting of 6 November 1975 in Geneva to contribute to the $\$ 100$ million EFTA development fund for Portugal. ${ }^{31}$ Nearly a year later, in October 1976, the Swiss parliament approved participation in the fund amounting to about CHF 63 million (one quarter of the total fund). Barely four months after a majority of Swiss voters had rejected a loan of CHF 200 million to the IDA, the Swiss parliament's approval of a contribution to the EFTA fund was, to observers, somewhat surprising. The French ambassador in Switzerland concluded that the catchwords of European solidarity and the fight against Communism in Portugal had been responsible for this result. ${ }^{32}$ But it also appears that aid for a European country was easier to sell in Switzerland than aid for Third World states.

In the latter half of 1975 , Swiss banks started to negotiate credit arrangements with Portugal. In late November 1975, the SNB granted a loan of $\$ 50$ million to the Banco de Portugal. The FPD welcomed this as a sign of Swiss goodwill towards Portugal and considered the timing of the decision to be extremely favourable. ${ }^{33}$ By the latter half of 1975 , the PCP had lost much support, as a civilian anti-Communist opposition formed around the PS and moderate officers gained influence within the MFA. A sixth provisional government, formed in early September, included the democratic parties and benefited from substantial US and Western European financial aid. With the failure of a coup staged by left-wing military forces on 25 November 1975, the

30 Claudio Caratsch, DPA, memorandum, "Assistance technique et économique au Portugal", o6.10.1975, dodis.ch/3906o; Jean-Jacques Maeder, Trade Division, memorandum, "Portuv gal: assistance économique. Réunion du 3 octobre 1975 avec MM. Ambassadeur Languetin; Jagmetti; Caratsch; Wiesmann; Streuli; Jetzer; Bru; Jg; Lo; Ae; Mr", o7.10.1975, dodis. $\mathrm{ch} / 39886$.

Jean-Jacques Maeder, memorandum, “AE LE: assistance financière au Portugal”, 29.10.1975, SFA E711O\#1986/24\#1024*; EFTA, Economic and Development Committee, "Essai de définition des modalités d'un fonds de l'AELE en faveur du Portugal. Note de la Délégation Suisse", 04.12.1975, ibid.; decree of the Federal Council, "AELE: Réunion ministérielle du 6 novembre 1975 à Genève. Instructions et delegation”, 05.11.1975, and attached proposals and reports by the FPD and the FDEA, dodis.ch/39898.

32 Letter from Claude Lebel, French ambassador in Switzerland, to Louis de Guiringaud, French Foreign Minister, "Participation de la Suisse au Fonds de développement institué par l'A.E.L.E. en faveur du Portugal", 05.10.1976, CAD 1929INVA/4683.

Minutes of the meeting of the SNB's directorate on 27 November 1975, "No. 1311. Kredit an Portugal", pp. 1908-1909, Archives of the Swiss National Bank, Zurich, Switzerland (ASNB); note from Ernesto Thalmann, secretary-general of the FPD, to Pierre Graber, strictly confidential, 28.11.1975, SFA E2Oo1E-o1\#1987/78\#4656*. See also the minutes of the meeting of the SNB's directorate on 30 October 1975, "No. 1187. Kredit an Portugal”, pp. 1729-1730, ASNB. 
prospect of a Communist takeover in Portugal had vanished. ${ }^{34}$ The SNB had a $10 \%$ participation in a $\$ 25$ o million ( $\mathrm{CHF} 645.3$ million) loan that the Bank for International Settlements (BIS) in Basel granted to Portugal in November 1975. In mid-1976, it contributed $\$ 55$ million to a loan of $\$ 25$ o million granted to Portugal by eight European central banks. ${ }^{35}$

Switzerland's provision of bilateral and multilateral financial aid to Portugal only took off once Portugal was set on a non-Communist path and a political and economic return on the investment might reasonably be expected. In the parliamentary elections of April 1976, the Ps won the most votes $(35 \%)$ and subsequently formed a minority government. General António Ramalho Eanes won the presidential elections and took office in June 1976 at the head of a constitutional democracy. ${ }^{36}$ In 1976, Swiss-Portuguese relations started to improve. Exports to Portugal, which had dropped by over $40 \%$ in 1975 compared to 1974, were growing once more. In September 1976, bilateral negotiations on economic collaboration and technical aid were resumed. ${ }^{37}$ The visit of the Portuguese Foreign Minister to Bern in January 1977 symbolised the normalisation of political relations between the two states. ${ }^{38}$ The cooling of bilateral relations that began in the second half of 1974 and the Portuguese leadership's preoccupation with domestic turmoil explain why the Portuguese government's position was rarely cited in Swiss decision-making during the decolonisation of Angola and Mozambique.

34 Maxwell, The Making of Portuguese Democracy, pp. 149-157.

35 Minutes of the meeting of the SNB's directorate on 17 November 1975, "No. 1262/6. Kredit an Portugal", pp. 1832-1833, ASNB; minutes of the meeting of the SNB's directorate on 8 January 1976, "No. 3/4. Kredit der BIZ an Portugal", p. 6, ibid.; minutes of the meeting of the SNB's directorate on 26 February 1976, "No. 197/2.1. Kredit der BIZ", p. 311, ibid.; minutes of the meeting of the SNB's directorate on 8 July 1976, "No. 620. Kredit der BIZ an Portugal", p. 987 , ibid.; minutes of the meeting of the SNB's directorate on 22 July 1976 , "No. 653 b. Zentralbankkredit an Portugal”, p. 1038, ibid. The sum has been converted to CHF using the exchange rates indicated in Officer, "Exchange Rates Between the United States Dollar and Forty-one Currencies".

36 Maxwell, The Making of Portuguese Democracy, pp. 16o-165.

37 Jean-Jacques Maeder, memorandum, "Commission mixte suisse-portugaise. 21-23 septembre 1976", late September 1976, dodis.ch/48598.

38 Letter from Claude Lebel to Louis de Guiringaud, "Visite du Ministre portugais des Affaires Etrangères à Berne”, 18.01.1977, p. 2, CADN 370PO/B/749; see also François Nordmann, FPD, minutes, "Visite officielle à Berne du Ministre des affaires étrangères du Portugal, M. José Manuel de Medeiros Ferreira, les 13 et 14 janvier 1977", 07.02.1977, dodis.ch/48124. 


\section{Aid and Recognition: Preparations for the Independence of the Portuguese Colonies}

In late July 1974, the Portuguese government promulgated a law recognising the right to self-determination of the African colonies. It expressed the new regime's commitment to decolonisation and opened the way for bilateral agreements on the transition of power to the PAIGC in Guinea-Bissau and FRELIMO in Mozambique. ${ }^{39}$ There was, as yet, no indication as to which liberation movement would come into power in Angola. The Swiss political and business elites started to prepare for the establishment of diplomatic and economic relations with independent Angola and Mozambique. This was all the more urgent as Switzerland's image problem in sub-Saharan Africa continued to grow. Heinz Langenbacher, Swiss ambassador in Ethiopia, warned his colleagues during the annual meeting of Swiss ambassadors in Bern in early September 1974 that economic collaboration with the white minority regimes in Southern Africa had started to undermine the credibility of Switzerland's neutrality policy. Members of the OAU accused the country of leading a "cynical, interest-driven policy that uses humanitarian actions as a smokescreen", which compared unfavourably with Sweden's "more idealistic policy". 40

Cold War considerations were noticeably less important to Bern's analysis of the situation after the Carnation Revolution in the Portuguese colonies than in Portugal. FPD officials rarely cited FRELIMO's and the PAIGC's links to the Eastern bloc or the possibility that the Marxist-inspired MPLA might take over in Angola to justify their position. At least until the internationalisation of the Angolan War in late 1975, Switzerland's Western ties played only a small role in the department's decision-making. This was certainly due to a lessening of international tensions in the context of Détente between the superpowers. Yet, the Swiss diplomats' greater political flexibility in Southern Africa can also be explained by the US government's comparatively passive role in this region. After Richard Nixon's resignation on 9 August 1974, due to his involvement in the Watergate scandal, the Ford administration had other priorities. Policy conflicts within the State Department, between the African Bureau attentive to the tenets of African nationalism and Secretary of State Henry Kissinger who focused on geopolitical aims, also contributed to this. ${ }^{41}$

\footnotetext{
39 MacQueen, The Decolonization of Portuguese Africa, pp. 88-92.

40 Statement of Heinz Langenbacher, minutes of the Annual Conference of Ambassadors 04.09.1974-o6.o9.1974, 30.09.1974, p. 75, dodis.ch/35118.

41

Schneidman, Engaging Africa, pp. 191-195.
} 
In order to prepare for the decolonisation of Angola and Mozambique, the Swiss government focused on two foreign policy instruments: the granting of humanitarian and development aid and diplomatic recognition of the soonto-be independent states. The recognition of a newly decolonised state is a prerequisite for the establishment of diplomatic relations. Since the Second World War, the Swiss government has recognised states, not governments. ${ }^{42}$ Its policy in this matter was guided by the principle of universality, which called for the diplomatic recognition of all states, no matter the political couleur of their regime. In actual fact, the decision of whether or not to recognise a state was always influenced by political considerations. This was particularly evident in the case of the divided states of Germany, Vietnam, and Korea. In all three cases, the Swiss government first recognised the pro-Western governments, and only in the early 1970s their Communist counterparts. ${ }^{43}$ In the context of decolonisation, the question of whether a colony achieved its independence in agreement with the colonising power was a decisive element in the Swiss government's recognition policy.

The Swiss government's position on the recognition of Guinea-Bissau after the PAIGC declared its independence on 24 September 1973 set a precedent for Swiss decision-making during the decolonisation of Angola and Mozambique. The PAIGC's unilateral declaration of independence was immediately recognised by many African governments. In early November 1973, the AfroAsian majority in the UNGA carried a resolution welcoming Guinea-Bissau's independence, in the face of opposition from Portugal, the US, the UK, Spain, Greece, Brazil, and South Africa. All other Western European states abstained. ${ }^{44}$ Two weeks later, Guinea-Bissau entered the OAU. ${ }^{45}$ In Bern, Swiss solidarity groups' demands for the recognition of the new state went unheeded. Reply-

42 Heinz Klarer, Die schweizerische Praxis der völkerrechtlichen Anerkennung, Zürich: Schulthess Polygraphischer Verlag, 1981, p. 294. See also Urban Kaufmann, "Nicht die ersten sein, aber vor den letzten handeln'. Grundsätze und Praxis der Anerkennung von Staaten und Regierungen durch die Schweiz (1945-1961)", in Antoine Fleury, Horst Möller, Hans-Peter Schwarz (eds.), Die Schweiz und Deutschland 1945-1961, Munich: R. Oldenbourg, 2004, pp. 69-87.

43 Switzerland finally recognised North Vietnam in September 1971, the GDR in December 1972, and North Korea in December 1974. On this subject, see Schaufelbuehl, Wyss, Bott, "Choosing Sides in the Global Cold War".

44 Letter from Bernard Turrettini, Ambassador at the Office of the Permanent Observer of Switzerland to the United Nations, to the Dio, "UNo: Republik Guinea-Bissau. Resolution 3061 (XVIII)", 05.11.1973, SFA E2001E-o1\#1987/78\#4649*. See also MacQueen, "Belated Decolonisation and UN Politics against the Backdrop of the Cold War".

45 Letter from Heinz Langenbacher to the DIO, "OAU: Guinea-Bissau", 19.11.1973, SFA E20o1Eol\#1987/78\#4649*. 
ing to a parliamentary question by Jean Vincent, National Councillor and member of the Swiss Workers' Party, the Federal Council argued in February 1974 that Guinea-Bissau did not meet the criteria required of a sovereign state under international law; there was no government that sovereignly and permanently exercised public authority over the population and territory, as the independence war was still ongoing. ${ }^{46}$ At the time, even the Swedish government, which had been the largest external donor to the PAIGC apart from the Soviet Union, did not yet plan to recognise Guinea-Bissau. ${ }^{47}$

The Portuguese coup d'état changed the situation. As the Scandinavian countries and the Netherlands considered recognising Guinea-Bissau even if the new Portuguese regime should continue to refuse negotiating with the PAIGC, FPD leaders started to contemplate doing the same. Given that Switzerland's economic interests in Guinea-Bissau were almost non-existent, their new willingness to recognise the new state was entirely political; they did not want Switzerland to be one of the last states to recognise Guinea-Bissau. ${ }^{48}$ As in the cases of the recognition of North Vietnam and North Korea, the Swiss government coordinated this step with its fellow European neutrals. While Sweden was one of the main advocates of the speedy recognition of GuineaBissau, the Austrian government saw no need to hurry, as there was hardly any public pressure to do so in Austria. ${ }^{49}$ In June 1974, the DiO decided to provide 10 tons of powdered milk to the population in Guinea-Bissau that the ICRC was to distribute, aid that it was hoped would make a favourable impression on the country's future rulers. ${ }^{50}$

46 Decree of the Federal Council, "(No 572) Petite question Vincent du 28 janvier 1974 concernant reconnaissance de la Guinée-Bissau", 13.02.1974, SFA E20o1E-o1\#1987/78\#3234*. See also the telegram from the KSA to Pierre Graber, 26.o9.1973, SFA E2001E-o1\#1987/78\#4649*; petition by numerous Swiss solidarity movements to the Federal Council, received on 16.01.1974, SFA E2001E-o1\#1987/78\#4649*.

47 Letter from Claude Ochsenbein, chargé d'affaires a.i. of the Swiss embassy in Sweden, to the DPA, "Relations Suède-Guinea-Bissau", 04.03.1974, SFA E2001E-o1\#1987/78\#3234*; Sellström, Sweden and National Liberation in Southern Africa. Volume II: Solidarity and Assistance, p. 64.

48 No author, memorandum, "3. Guinea-Bissau", 24.04.1975, attached to the note from the FPD to Federal Councillor Pierre Graber, 25.04.1975, SFA E20o1E-o1\#1987/78\#1683*; HN, memorandum, "Visite Kirchschläger. Guinée-Bissau: remarques introductives”, 02.05.1974, SFA E2001E-o1\#1987/78\#3234*.

49 No author, excerpt of minutes, "Extrait du procès-verbal des entretiens avec M. Kirchschläger du 3 mai 1974", no date, SFA E2Oo1E-ol\#1987/78\#3234*; Karl Fritschi, DPA, memorandum, "Anerkennung von Guinea-Bissau. Schwedens Haltung", 07.06.1974, ibid.

50 Letter from René Keller to the Swiss embassy in Guinea, 20.06.1974, SFA E2001Eol\#1987/78\#3234*; letter from Benoît Frochaux, chargé d'affaires a.i. of the Swiss embassy in Guinea, to the DIO, 01.07.1974, ibid. 
On 9 August 1974, the Portuguese authorities concluded an agreement in principle on decolonisation with the PAIGC. Sweden and Finland immediately recognised Guinea-Bissau. Ceding to international pressure, the Portuguese Foreign Minister invited the ambassadors of states that had not yet recognised Guinea-Bissau to a meeting, hinting that Lisbon was no longer opposed to such a step. ${ }^{51}$ As the EEC member states and Austria, a member of the UN Security Council, recognised Guinea-Bissau, on 12 August the Secretary General of the FPD suggested that the Federal Council should not hesitate any longer: "Otherwise, we will finally be among the last to maintain the fiction of the colonial status." ${ }^{52}$ The Federal Council recognised Guinea-Bissau the following day, before this territory's formal independence. On 10 September, Guinea-Bissau was the first Portuguese colony to be officially granted independence. A week later, it joined the UN. ${ }^{53}$

The case of Guinea-Bissau indicates some of the factors that would influence Swiss decision-making when it came to the recognition of Mozambique and Angola; the granting of humanitarian aid, close attention to the position of the colonial power, the desire to be neither the first nor the last to recognise a new state, and attempts to coordinate decisions with the other European neutrals and the EEC. Yet, Swiss recognition of Guinea-Bissau, like that of other Western states, can also be read as a sign of Third World power. In a context of mounting Afro-Asian criticism of Western collaboration with the white minority regimes in Southern Africa, Western governments were under pressure to show their support for African nationalism. In the case of the recognition of Guinea-Bissau, this could be done at minimal political and financial cost.

After the Western recognition of Guinea-Bissau, international attention turned to Mozambique. In mid-August 1974, for the first time since the Carnation Revolution, Swiss embassy officials in Washington discussed the situation in Portuguese Africa with the US Deputy Assistant Secretary of State for African Affairs, Edward William Mulcahy. The latter underlined that, although developments in this region were not a priority of Washington's foreign policy, they did receive high-level attention. In a report to Bern, Olivier Exchaquet, the chargé d'affaires of the Swiss embassy, commented that the Ford

$5^{1} \quad$ Telegram no 7 o from Jean-Louis Pahud to the DPA, 10.08.1974, SFA E2Oo1E-o1\#1987/78\#3234*; telegram no 50 from Charles Müller to the Swiss embassy in Lisbon, 07.08.1974, ibid.; telegram no 85 from Peter Friederich, Swiss embassy in Finland, o9.08.1974, ibid.; letter from Claude Ochsenbein to the DPA, "Reconnaissance de la Guinée-Bissau", 12.08.1974, ibid. SFA E2001E-o1\#1987/78\#3234*.

53 Telegram no 12 from Alfred Reinhard Hohl, DPA, to the Swiss embassy in Guinea, 13.08.1973, SFA E20o1E-o1\#1987/78\#3234*; MacQueen, The Decolonization of Portuguese Africa, p. 109. 
administration's Africa policy lacked direction: "One gets the impression that $\mathrm{X}$ [Mulcahy] is preoccupied with the consequences of Mozambique's independence, but that the State Department has no plan at all to cope with possible troubles. ${ }^{54}$ Exchaquet would come to a similar conclusion regarding the Ethiopian Revolution only a month later. Consequently, Switzerland's Africa policy was, in the following years, more closely coordinated with the other neutral and Western European states than with the US.

On 7 September 1974, the Portuguese authorities and FRELimo concluded the Lusaka Agreement, which established the legal framework for the decolonisation of Mozambique. The agreement introduced an official ceasefire after 11 years of war and set the terms for FRELIMO to take over without holding elections. A transitional government consisting of FRELIMO members and Portuguese representatives took over the running of Mozambique until its independence, set for 25 June 1975 . The Portuguese military quickly put down an attempted coup in Lourenço Marques staged by groups of white settlers and Africans hostile to FRELIMO.$^{55}$ In early October 1974, two delegations of Swiss citizens living in Mozambique visited Bern to demand governmental support during decolonisation. A group of DM and IPM members requested financial aid to continue their humanitarian efforts. The missionaries also hinted that early recognition of Mozambique might compensate for Switzerland's former lack of support for African liberation movements. ${ }^{56}$ Representatives of the major Swiss companies in Mozambique raised the spectre of nationalisations. The risk that FRELIMO might introduce a Soviet-style system of economic development or Tanzanian-style nationalisations and collective agriculture schemes was mentioned in numerous reports by Swiss diplomats in Portugal, Tanzania, and Mozambique. ${ }^{57}$ Convinced of the importance of establishing, at

54 PR no 78 from Olivier Exchaquet, chargé d'affaires a.i. of the Swiss embassy in the US, "Le désengagement portugais en Afrique vu de Washington", 16.08.1974, p. 5, SFA E230oo1\#1977/30\#88*.

55 Newitt, "Mozambique", p. 193; MacQueen, The Decolonization of Portuguese Africa, pp. 146-148.

56 Claude Huguenin, memorandum, "Visite de membres du Département missionnaire de Lausanne et de l'Eglise presbytérienne du Mozambique”, 14.10.1974, p. 2, SFA E2200.167\#1991/284\#21*.

Letter from Jean-Louis Pahud to the DPA, 27.09.1974, very urgent, SFA E20o1E-o1\#1987/ 78\#4651*; PR no. 8 from Lucien Mossaz, "Prévisions sur la politique du Mozambique", o1.10.1974, SFA E2OO1-09\#1984/68\#85*; letter from Mossaz to the Trade Division, "La politique économique du Mozambique indépendant”, o3.10.1974, SFA E 7110\#1985/97\#500*; see also telegram no 11 from the Swiss consulate in Mozambique to the FPD, 27.09.1974, SFA E20o1E-o1\#1987/78\#4651*; telegram no 6o from Alfred Reinhard Hohl to the Swiss embassy in Portugal, 26.o9.1974, SFA E2Oo1E-o1\#1987/78\#4651*; letter from Louis Rochat, 
the very least, informal contact with FRELIMO as soon as possible, the deputy chief of the DPA, Michael Gelzer, requested these diplomats to report on the plans of the Scandinavian states, the EEC, and Austria. ${ }^{58}$ On 30 October 1974, while these strategic clarifications were ongoing, the Federal Council decided to recognise Mozambique after full independence and authorised the FPD to determine the date of official recognition. . $^{9}$

The FPD leaders' wish to get on good terms with Mozambique's future rulers was part of their growing efforts to show more openness towards the Third World. Symptomatic of this was an increasing awareness that Switzerland's negative attitude towards liberation movements had been short-sighted, as the chief of the DIO's section for the UN and international organisations, Franz Muheim, stated in a note to his supervisor in late October 1974:

We probably neglected to take into account that today's leaders of liberation movements are often the same people that will be responsible for the government of independent states tomorrow, states we will recognise and establish diplomatic relations with, but also states on whose goodwill we will depend to some degree, because they host Swiss colonies, Swiss investments, and other Swiss economic interests. ${ }^{60}$

The lack of Western support had, according to him, forced these movements to seek aid elsewhere and had subjected them to the influence of the Eastern bloc. ${ }^{61}$ Richard Pestalozzi's criticism of the official Swiss policy on Southern Africa was even more explicit. Referring to the Ethiopian attacks against Switzerland linked to the controversy surrounding the Emperor's Swiss bank accounts, he warned that the country's good name might suffer if its government did not take a stand and use all its means to limit economic exchanges

Financial and Economic Service of the FPD, to the SNB, the SBA, and the Federation of Swiss Industrial Holding Companies, "La politique économique du Mozambique indépendant", o9.10.1974, ASBA, folder L. 182 Afrique 5.1.71 au 14.7.75.

$5^{8}$ Letter from Michael Gelzer, Deputy Chief of the DPA, to the Swiss embassies in Portugal and Tanzania and the consulate in Mozambique, "Schweizerische Interessen in Mozambique", o3.10.1974, SFA E2001E-o1\#1987/78\#4651*.

59 Decree of the Federal Council, "Anerkennung von Mozambique durch die Schweiz", 30.10.1974, SFA E2001E-o1\#1987/78\#4178*.

6o Note from Franz Muheim, chief of the Dio's section for the UN and international organisations, to René Keller, "OLP - Afrikanische Befreiungsbewegungen; Stellung der Schweiz", 29.10.1974, p. 3, SFA E2003A\#1988/15\#573*.

$61 \quad$ Ibid., p. 4. 
with South Africa. ${ }^{62}$ However, since the majority of the Federal Council was unwilling to curtail Switzerland's economic relations with South Africa, and the development of legal measures to limit trade with Rhodesia advanced only slowly, the sole remaining means to improve Switzerland's image in Southern Africa was the granting of humanitarian aid to the liberation movements in this region. ${ }^{63}$

Consequently, in reply to a request from a committee of Portuguese, Swiss, and Dutch religious organisations for aid to support famine-stricken provinces in Mozambique, the Swiss authorities granted food aid amounting to $\mathrm{CHF}$ 140,000. ${ }^{64}$ Many FPD officials agreed that a gesture of goodwill towards the Mozambican population was "politically desirable" as a sign of a Swiss presence in Mozambique "beyond purely mercantile motives", as Michael Gelzer put it in late November. ${ }^{65}$ This was all the more important as, in mid-October, European and African newspapers had started to spread rumours about a Swiss millionaire attempting to recruit mercenaries to prevent FRELIMO's takeover. Investigations by the Office of the Attorney-General of Switzerland concluded, in December 1974, that the rumours were untrue and that the millionaire, a rather ambivalent character who had a profitable business helping people escape from the GDR, had only been drawing attention to himself. Nevertheless, this affair was embarrassing for the Swiss government, which continued to be confronted by these rumours until early $1975 \cdot{ }^{66}$

62 PR by Richard Pestalozzi, "Die Schweiz und der Konflikt um die weissen Regime in Südafrika", 14.11.1974, SFA E2003A\#1988/15\#1508*.

63 Letter from Michael Gelzer to the Swiss embassy in Kenya, 23.12.1974, SFA E2001E-o1\#1987/ 78\#4329*.

64 Note from Denise Werner, chief of the Dio's International Aid Organisations Section, to the DPA, "Aide humanitaire sollicité au faveur du Mozambique", 20.11.1974, SFA E2001E-o1\#1987/78\#4651"; letter from René Keller to the KSA, 12.12.1974, SFA E2200.54○ß $1992 / 228 \# 38^{*}$.

65 Note from Michael Gelzer to the International Aid Organisations Section of the DIo, "Humanitäre Hilfe an Moçambique", 26.11.1974, SFA E2001E-o1\#1987/78\#4651*. See also the note from Denise Werner to the DPA, "Aide humanitaire sollicité au faveur du Mozambique", 20.11.1974, ibid.; letter from Jean-Louis Pahud to the DPA, "Schweizerische Interessen in Mozambique", 21.11.1974, ibid.

66 Telegram no 81 from Richard Pestalozzi to the FPD, 23.10.1974, SFA E2001E-o1\#1987/78\#4651*; letter from Bernard Torrione, Swiss Consul-General in Milano, Italy, to the DPA, 24.10.1974, ibid.; letter from Alfred Reinhard Hohl to the Office of the Attorney-General of Switzerland, 30.10.1974, ibid.; letter from Louis Chaney, Swiss consul in Mozambique, to the DPA, "Mercenaires pour le Mozambique", 07.11.1974, ibid.; letter from Etienne Vallotton, Swiss ambassador in Algeria, to the DPA and the Information and Press Service of the FPD, 26.11.1974, ibid.; letter from Rudolf Gerber, Attorney-General, to the FPD, 16.12.1974, ibid., and the attached report from [?] Lörtscher, Zurich City Police, to the Office of the Attor- 
In late 1974, FPD leaders observed the tense situation in Angola with great interest and ordered the Swiss honorary consul in Luanda to write regular reports. ${ }^{67}$ However, for several reasons, they did not yet take any steps to establish political contact with the country's future rulers. First, the Portuguese authorities had not yet concluded a decolonisation agreement with the rivalling Angolan liberation movements. Second, the Swiss authorities had no information about significant Swiss investments in this state that would have justified a proactive stance. Finally, anti-Communism might also have played a role. In a letter to the Swiss ambassador to Zaire in mid-November, Alfred Hohl of the DPA expressed his worry that forces might gain influence in Angola that "are closer to Brazzaville or Dar es Salaam and might thus obtain their schoolbooks from Moscow rather than from the West". ${ }^{68}$

In mid-January 1975, the Portuguese government and the three Angolan liberation movements, which had been pressured by the OAU and independent African governments to present a common front in the negotiations with the colonial power, concluded the Alvor Agreement. It set the terms for Angola's accession to independence on 11 October 1975 and created a transitional government consisting of a Portuguese High Commissioner and a presidential council with a representative of each movement. The twelve ministries were divided equally between the three movements and Portugal. 69 As a consequence, the DPA started to make detailed plans for Switzerland's future relations with Mozambique and Angola. The establishment of diplomatic relations with these two states was judged important for two reasons: first, it would counterbalance Switzerland's close links with South Africa; second, it would make it easier for Swiss firms to benefit from the economic potential of Angola and Mozambique. Hydroelectric projects in these territories, their deepwater

ney-General of Switzerland, 13.11.1974; letter from Heinz Langenbacher to the DPA, "OAU", 20.01.1975, ibid.; letter from [?] Ritter, Swiss embassy in Libya, to the DPA, "Neutralität der Schweiz. Söldner für Mozambique”, 05.04.1975, ibid. See also Stefan Hohler, Hans Ulrich Lenzlinger. Fluchthelfer, Abenteurer und Lebemann, Bern: Stämpfli, 2013.

67 Letter from Alfred Reinhard Hohl to Roland Gottraux, O2.10.1974, SFA E2200.54-O3\#1992/ $228 \# 252^{*}$, see also letter from Gottraux to the FPD, 22.09.1974, SFA E2200.54-03\#1992/ $228 \# 252^{*}$.

68 Letter from Alfred Reinhard Hohl to the Swiss Embassy in Zaire, 12.11.1974, SFA E2001E-o1\#1987/78\#4650*. See also the letter from Hohl to the Trade Division, 22.11.1974, ibid.; letter from Jean-Louis Pahud to the DPA, "Schweizerische Interessen in ANGOLA", 03.12.1974, SFA E2001E-o1\#1987/78\#4651*; letter from Hans Lüthi, Trade Division, to the DPA, "Wirtschaftsbeziehungen mit Angola", og.12.1974, SFA E7110\#1985/97\#457*.

69 Gleijeses, Conflicting Missions, p. 242; MacQueen, The Decolonization of Portuguese Africa, pp. 174-176; Marcum, Exile Politics and Guerrilla Warfare, p. 255. 
ports, and their natural resources, especially Angola's oil, were considered to be of particular interest to Swiss companies and investors. ${ }^{70}$

In parallel, the STC decided to grant development aid to Mozambique and Guinea-Bissau. Angola was excluded from these plans because of its political instability. The Soviet ties of FRELIMO and the PAIGC were not seen as an obstacle. The Delegate for Technical Cooperation even considered that the two states' socio-economic policies favouring the rural population would facilitate the selection of suitable cooperation projects. ${ }^{71}$ However, because of difficulties in identifying projects that met the STC's criteria, the service decided, in July 1975, to wait before taking up direct bilateral cooperation with Mozambique. Instead it made financial contributions to projects carried out by the Food and Agriculture Organization (FAO), the United Nations Children's Fund (UNICEF), and the DM. ${ }^{72}$

During the first half of 1975, the continuing conflict between the three Angolan liberation movements made it very uncertain who the country's future rulers would be. Clashes between the FNLA and the MPLA turned increasingly violent, while Portuguese troops proved unwilling to enforce the Alvor Agreement. UNITA kept out of the fighting and consolidated its political and military support. ${ }^{73}$ In this context, the DPA was careful not to favour one liberation movement over another, in order to keep its diplomatic options open, and cited its policy of neutrality to justify its non-committal stance. For example, when two representatives of UNITA approached a Swiss diplomat in Geneva in early February 1975 to convey their leader's wish to establish relations with Switzerland, the diplomat replied with what would become a standard phrase during the following months: "Switzerland cannot take position in favour of one of the three liberation movements, this would represent an interference into the internal affairs of Angola". ${ }^{74}$

$70 \quad$ FPD, memorandum, "Angola \& Mozambique", no author, no date, attached to a note from Alfred Reinhard Hohl to Charles Glauser, FPD, 03.02.1975, SFA E2004B\#199o/219\#344*.

71 Note from Marcel Heimo, Delegate for Technical Cooperation, to the DPA, "Coopération technique avec le Mozambique, l'Angola et la Guinée-Bissau”, 10.02.1975, p. 3, SFA E2005A\#1985/101\#547*.

72 Note from Marcel Heimo to the DPA, "Technische Zusammenarbeit mit Mozambique", 08.07.1975, SFA E2005A\#1985/101\#547*; see also the note from Serge François Salvi, head of the STC's Africa section, to Claude Huguenin, "Coopération avec le Mozambique", o3.06.1975, ibid.

73 Gleijeses, Conflicting Missions, pp. 251-253.

74 Note from Jean Schneeberger, Permanent Mission of Switzerland to the United Nations Office and the other international Organisations in Geneva, to André Dominicé, chief of the Permanent Mission, 07.02.1975, SFA E2001E-o1\#1987/78\#4650*. 
Unofficial contacts were a different matter. After the fall of the Estado Novo regime, the fact that the Swiss authorities had, in the 196os, granted political asylum to a number of Angolan refugees offered a potential diplomatic opportunity. Two members of the Angolan transitional government and three state secretaries, all but one members of UNITA, had lived in Switzerland during the liberation war. Other former refugees occupied high positions within the liberation movements. The most prominent of these were José N'Delé, UNITA's representative in the presidential council, and Jonas Savimbi, the movement's leader, both of whom were married to Swiss citizens. ${ }^{75}$ FPD officials considered the Swiss ties of these influential Angolans to be an advantage for the establishment of good relations with an independent Angolan government. Thus, in early 1975, they unofficially cultivated their relations with former Angolan refugees. On the one hand, this enabled them to obtain privileged information about the situation in Angola and the plans of the liberation movements. On the other hand, with an eye on the long term, they hoped that possible future leaders of this country would be well disposed towards Switzerland.

In early March 1975, for example, a D PA representative met with FNLA member Albert Tanda before the latter's departure from Switzerland to take on a high-level post in Luanda. During their discussion, Tanda made it clear that the FNLA was unwilling to share power and wanted to establish a military government in Angola. ${ }^{76}$ While this prospect did not appeal to the Swiss authorities much more than the MPLA's ideological leanings, the Swiss authorities' perception of UNITA and its leader was overwhelmingly positive. In a report to Bern in March 1975, the Swiss consul in Angola described Jonas Savimbi as an "intelligent leader", "non-racist", commanding a well-disciplined army and having the least "leftist" political programme of the three Angolan movements. ${ }^{77}$ Inspector René Gailloz of the Federal Police, who had been in regular contact with N'Delé and Savimbi during their time in Switzerland, insisted that Savimbi was a "very moderate politician and well-disposed towards our

75 René Gailloz, inspector of the Federal Police, memorandum, "Gouvernement de transition angolais et anciens réfugiés angolais en Suisse”, 30.04.1975, SFA E2001E-o1\#1987/78\#4650*. See also Giovanni E. Bucher, Swiss ambassador in Portugal, to the AD, "Démission de M. R.P Gottraux, Consul hon. de Suisse à Luanda", 12.02.1975, SFA E2200.54-03\#1992/228\#252*.

76 Claude Huguenin, memorandum, "Visite du ressortissant angolais M. Albert TANDA", 13.03.1975, p. 2, SFA E2001E-01\#1987/78\#4650*.

77 Marcel Guélat, Swiss consul in Angola, to the AD, confidential, 24.03.1975, pp. 4-5, SFA E2001E-01\#1987/78\#4650*. 
country",78 and that his movement was not steered from outside, "unlike the protégés of President Mobutu of Zaire (FNLA) or of the Soviet bloc (MPLA)."79

Despite this positive reading of UNITA, the Swiss authorities remained careful not to openly favour the movement. They took greater care to appear impartial during the early stages of the Angolan conflict than their Swedish counterparts. In February 1975, Sweden's Social Democratic government, which had close and long-standing links with the MPLA, decided to honour a bilateral aid agreement concluded with the movement the year before. Despite some domestic criticism that this constituted undue interference in Angola's internal affairs, Swedish representatives continued their consultations with the MPLA and their initial, very limited, humanitarian aid was disbursed just before the independence of Angola in November 1975. This aid relationship amounted to a de facto recognition of the MPLA as Angola's legitimate future government, which was clearly understood both by the MPLA and its two opponents..$^{80}$

The clashes between the liberation movements rendered it more difficult for the FPD to make its humanitarian aid appear neutral and disinterested. In early 1975, for example, the FNLA requested urgent Swiss help to train nurses. Jean-Pierre Weber, Swiss ambassador to Zaire, argued in late March that "[o]bviously, our attitude must be to win the future leaders without moving away from our traditional position or taking position in the conflict". ${ }^{81}$ Caught between the political potential of granting humanitarian aid to the Angolan population, and a certain reluctance to support a potential future warring party, the DPA decided that this request could only be considered if it was channelled through the provisional government. ${ }^{82}$ With the intensification of the Angolan conflict from mid-1975 onwards, members of the FPD insisted that every Swiss aid project had to benefit all three warring parties equally, ${ }^{83}$ so as not to endanger Switzerland's policy of neutrality.

78 Cited in Alfred Reinhard Hohl, memorandum, 10.04.1975, SFA E20o1E-o1\#1987/78\#4650*.

79 René Gailloz, memorandum, "Gouvernement de transition angolais et anciens réfugiés angolais en Suisse”, 30.04.1975, p. 3, SFA E2Oo1E-o1\#1987/78\#4650*.

8o Sellström, Sweden and National Liberation in Southern Africa. Volume II: Solidarity and Assistance, pp. 129-131.

81 Jean-Pierre Weber, Swiss ambassador in Zaire, to the DPA, confidential, 27.03.1975, p. 2, SFA E2005A\#1985/101\#230*.

82 Note from Alfred Reinhard Hohl to the DIO and the Delegate for Technical Cooperation, "Angolesisches Gesuch um Ausbildung von Krankenschwestern", 08.04.1975, pp. 1-2, SFA E2005A\#1985/101\#230*. It seems that this project was never realised.

83 See, for example, Renata Carugo, sTc, to the Delegate for Technical Cooperation, "Entrée en matière", 26.o6.1975, p. 2, SFA E2005A\#1985/101\#114*. 
Due to the growing political instability, the FPD intensified its preparations for Angola's independence. In March 1975, the department sent career diplomat Marcel Guélat to take over the consulate in Luanda. The new consul soon concluded that a continuing official presence in the country was essential in order to show Switzerland's interest in Angola and ensure the evacuation of the approximately 100 Swiss citizens living in the country if the situation should deteriorate. A representative on the spot would also allow the Swiss authorities to quickly establish contact with the future government in order to ensure Switzerland's place in the future industrialisation of Angola. ${ }^{84}$ The Federal Council shared this view and decided, in June 1975, to recognise Angola after it achieved 'full independence'. ${ }^{85}$ It was left to the FPD to determine when this would be.

In Mozambique, meanwhile, the FPD sought to establish good relations with the country's new elite. This proved to be much more difficult than its members imagined. In early 1975, FRELIMo's leadership adopted a confident stance and showed great reticence towards the US and those Western European states it considered to have been allied to the Portuguese colonial power. Thanks to its selective interpretation of neutrality, Switzerland was seen as part of this camp. The Swiss embassy in Tanzania and consul Bruno Stöckli, who took on his post in Lourenço Marques at the beginning of February, attempted to make contact with FRELIMO in order to prepare for the establishment of official relations after Mozambique's independence. Two developments added urgency to their advances: first, the danger of nationalisations became real. In mid-February, the transitional government enacted a law permitting the nationalisation of empty buildings that targeted mainly the property of foreigners who had left the country in the preceding year. Second, FRELIMO's leaders made it known that they were unwilling to establish relations with diplomats that had received their accreditation from the colonial authorities and would not automatically accept the transformation of consulates, established under Portuguese rule, into embassies. ${ }^{86}$ Yet, all Swiss attempts to obtain an audience with FRELIMo's Vice-President, Marcelino dos Santos, who was

\footnotetext{
84 Marcel Guélat to the AD, "Mission en Angola - Rapport", o8.04.1975, pp. 8, 11-12, SFA E2200.54-O3\#1992/228\#252*.

85 Decree of the Federal Council, "Anerkennung von Angola durch die Schweiz", confidential, 16.06.1975, SFA E2001E-o1\#1987/78\#1683*.

86 Letter from Bruno Stöckli, Swiss consul in Mozambique, to the AD, very urgent and confidential, 21.02.1975, SFA E2001E-o1\#1987/78\#4178*; letter from Stöckli to the DPA, "Mozambique. Wahrung von schweizerischen Interessen", 14.03.1975, SFA E2001E-01\#1987/78\#4182*.
} 
responsible for the movements' external relations at its headquarters in Dar es Salaam, were unsuccessful. ${ }^{87}$

This was not, in itself, extraordinary. Other Western states were facing similar dismissal. FRELIMo's leadership greatly distrusted the US government. In order to dispel suspicions of imperialist US designs, the American consul general, Peter C. Walker, recommended in late March 1975 that the Ford administration should recognise Mozambique immediately after its independence and be open to aid requests, but otherwise adopt a low profile. Walker insisted that FRELIMO wished to have diplomatic contact with both blocs. According to him, there was no reason to think that US interests should be affected any worse than "in the many other militantly 'non-aligned' African countries". 88 Thanks to their common interest in introducing majority rule in Rhodesia, and thanks to a generous British aid offer of $£_{15}$ million (CHF 83.7 million), the UK managed to get in touch with FRELIMO more quickly. A meeting between Samora Machel, the movement's leader, and the British Minister of Overseas Development was held on 10 May 1975 in Dar es Salaam, where they discussed future bilateral relations. ${ }^{89}$

A breakthrough in Swiss-Mozambican relations occurred on 22 May 1975. Through the intermediary of Hanna Sahlfeld-Singer, Social Democratic member of the National Council and Vice-President of the Südafrika Mission (South Africa Mission), two FRELIMo representatives who were passing through Switzerland were received by the DPA in Bern. This meeting proved that the alliances made during the independence war were still crucial for the liberation movement. The two Mozambicans compared Switzerland's selective interpretation of neutrality to Sweden's policy of neutrality, and judged its position

$87 \quad$ PR no 2 by Bruno Stöckli, "Mozambique. Entkolonialisierung und ihre Nebenerscheinungen”, 20.03.1975, p. 3, SFA E2300-01\#1977/30\#51*. Letter from Raymond Berberat, chargé d'affaires a.i. of the Swiss embassy in Tanzania, to the DPA, "Kontakte mit FRELIMO-Führung", 16.05.1975, SFA E2001E-o1\#1987/78\#4651.

88 Airgram from Peter C. Walker, US Consul General in Mozambique, to the Department of State, “Annual U.S. Policy Assessment - Mozambique", 25.03.1975, p. 9, see also 10; NARA, RG 59, Records Relating to Portuguese Guinea, Mozambique 1975, box 6 .

89 H.M.S. Reid, head of the CSAD, draft memorandum, no date, attached to the note from Reid to several department heads, 05.03.1975, TNA FCO 45/1732; no author, "Record of a meeting between President Samora Machel and other frelimo leaders and the Rt Hon Judith Hart MP, Minister of Overseas Development, in State House Dar es Salaam on 10 May 1975", no date, TNA FCO 45/1734; see also H.M.S. Reid to Norman Aspin, Assistant Under-Secretary of State, FCO, "Proposal for Samora Machel to visit London", 08.04.1975, TNA FCO 45/1732; Reid to Aspin, "Samora Machel”, 15.04.1975, ibid. The sum of $£_{15}$ million has been converted to CHF using the exchange rates indicated in Officer, "Exchange Rates Between the United States Dollar and Forty-one Currencies". 
during the conflict against that of Norway, Denmark, and the Netherlands, which had supported FRELIMO's independence struggle, and that of the UK. They also criticised the Swiss authorities for waiting too long before contacting FRELIMO. DPA leaders tried to deflect these accusations with information about possible humanitarian and development aid. ${ }^{90}$ They did not take up the suggestion to publish a communiqué on Switzerland's willingness to establish relations with Mozambique, considering it impossible to draft a text that satisfied both sides. ${ }^{91}$ Instead, they tried to obtain an official invitation to the Mozambican independence celebrations on 25 June 1975, in order to publicly show their support for independent Mozambique.

Invitations to the independence festivities were selective and reflected FRELIMO's priorities in foreign relations. While African and Eastern bloc states were welcomed to Mozambique, only Portugal, the UK, the Scandinavian countries, and the Netherlands received formal invitations. Unofficial groups from the US, the FRG, and Italy were also present. ${ }^{92}$ While the Ford administration does not seem to have been overly concerned about such treatment, the French authorities were particularly piqued and feared that it might damage their standing in Africa..$^{93}$ Their attempts to convince the other EEC member states to aim for a collective representation at the ceremonies failed and the French ambassador to Tanzania was explicitly told by a FRELIMO official to stay away from the festivities. ${ }^{94}$

In this context, the Swiss authorities again benefited from the connections of Swiss missionary circles. Thanks to the good offices of a DM member, who had been personally invited by Samora Machel to head up a delegation of Swiss churches, the FPD learned, four days before Mozambique's independence, that

$90 \quad$ Claude Huguenin, memorandum, "Premiers contacts à Berne avec les représentants du Frelimo", 26.05.1975, SFA E2001E-o1\#1987/78\#4651. See also the letter from National Councillor Hanna Sahlfeld-Singer to Pierre Graber, 30.04.1975, SFA E2001E-o1\#1991/17_Bd. 985, B.55.40.

91 Telegram no 36 from Jürg Andreas Iselin, deputy chief of DPA and chief of its African, Asian, Middle Eastern and Latin American Division, to the Swiss embassy in Tanzania, 20.06.1975, SFA E2001E-o1\#1987/78\#4178*.

92 Report from Stanley F. St. C. Duncan to James Callaghan, British Foreign Secretary, "Moçambique independence: visits by Minister of State, the Rt Hon Mr. David Ennals, MP, 24-26 June 1975", 30.06.1975, pp. 1-2, TNA FCO 45/1735.

Telegram from Peter C. Walker to the US Secretary of State, o9.05.1975, NARA, RG 59, AAD, CFPF, Electronic Telegrams 1975LOURENoo474; MC, Direction des affaires africaines et malgaches (DAM), memorandum, "Indépendance du Mozambique", 26.05.1975, p. 1, CAD 342QONT/6.

94 Telegram no 159-161 from Georges Denizeau, French ambassador in Tanzania, to the French Foreign Ministry, 18.06.1975, CAD 342QONT/12. 
its delegate would be welcome in Mozambique. ${ }^{95}$ Switzerland's role as a host of numerous international organisations may also have helped to soften FRELIMO's leadership. ${ }^{96}$ Despite the unorthodox way in which the Swiss delegate Paul Etienne Jaccaud, the new Swiss ambassador to Tanzania, had received his invitation to the independence ceremonies, he was received with all honours. Only Marcelino dos Santos showed hostility to the delegation of "capitalist Switzerland". Dos Santos' criticism of the lack of Swiss support for the Mozambican independence struggle was compounded by a personal grievance; during a trip to Switzerland in December 1974, where he gave a press conference and interviews organised by the DM, he was apparently refused an audience by the Swiss authorities. DPA leaders, however, did not recall this incident. ${ }^{97}$

On 25 June 1975, the day of Mozambique's independence, Pierre Graber sent a congratulatory telegram to Samora Machel, which equated to official recognition of the new state. ${ }^{98}$ Ten days earlier, the Swiss government had decided to recognise Angola after its independence. However, the situation escalated rapidly. In July, after heavy fighting, the MPLA expelled the FNLA from Luanda and the transitional government collapsed. FNLA leader Holden Roberto left Zaire and led his movement's march towards Luanda, while unita fought MPLA troops in central and southern Angola. That same month, President Ford approved covert CIA support for the FNLA and UNITA, and South Africa increased its aid to those two movements, while Cuba sent a mission to Angola to determine the MPLA's need for aid. ${ }^{99}$

At least until the Angolan War, which is discussed in chapter 7, the political necessity of establishing cordial contact with the governments of independent

95 Letter from Bruno Stöckli to the DPA, "VR Mozambique. Schweizerische Teilnahme an den Unabhängigkeitsfeierlichkeiten”, og.o7.1975, p. 1, SFA E2001E-o1\#1987/78\#4178*; JeanPaul A. Widmer, DM, memorandum, "Note concernant les contacts entre le Département Politique Fédéral et les envoyés du gouvernement de la République Populaire du Mozambique, précédemment Frelimo", 30.09.1975, pp. 3-4, SFA E2001E-o1\#1987/78\#4651.

96 Telegram from Peter C. Walker to the Secretary of State, 03.07.1975, NARA, RG 59, AAD, CF PF, Electronic Telegrams 1975, 1975LOURENoo717.

97 Letter from Paul Etienne Jaccaud, Swiss ambassador in Tanzania, to the DPA, the AD, and the Trade Division, "Indépendance du Mozambique", o3.07.1975, p. 2, E2001E-o1\#1987/ $78 \# 4178^{*}$. This episode is mentioned in several SFA documents, but FPD members were at a loss to know if it had really taken place and if yes, who had refused to see dos Santos: see notably the handwritten comments on telegram no 23 from Bruno Stöckli to the FPD, urgent, 08.o3.1976, SFA E2OO1E-o1\#1988/16\#46o2*.

98 Telegram from Pierre Graber to Samora Machel, President of Mozambique, 25.06.1975, SFA E2Oo1E-o1\#1987/78\#4178*.

99 Gleijeses, Conflicting Missions, pp. 254, 257-258; Marcum, Exile Politics and Guerrilla Warfare, pp. 260-262; Miller, "Yes, Minister", p. 17. 
Angola and Mozambique was undisputed, both within the Swiss federal administration and in civil society. The danger that existing Swiss interests in the Portuguese colonies might be nationalised and Swiss economic actors' wish to benefit from the two states' economic potential after the departure of the colonial authorities spurred Bern's efforts to get on good terms with the potential future rulers. Yet, as there were few commercial exchanges and Swiss investments, economic aspects were not decisive. The will to improve Switzerland's image and the credibility of its neutrality in Africa was key to its foreign policy during the decolonisation of Angola and Mozambique. The establishment of cordial relations with the countries' new rulers, which was supported by Swiss business circles and solidarity movements, was a low-cost means to counterbalance relations with the minority regimes. It also showed Third World observers that Switzerland was not racist and was supportive of newly independent black governments.

\section{"The Game Being Played Is Global": Attempts to Strengthen} Relations with the Third World

In mid-December 1974, foreign policy expert Walther Hofer, National Councillor for the conservative centre-right Swiss People's Party and a history professor at the University of Bern specialising in totalitarian systems and ideologies, requested the government to comment on Switzerland's position in what he termed a "new kind of Cold War" - a time when the Western world was under pressure not only from the USSR but also from the newly decolonised states of the Third World that engaged in "economic blackmail" at the UN and its specialised agencies. ${ }^{100}$ When replying to Hofer's query six months later, shortly before Mozambique became independent and the Angolan War escalated, Federal Councillor Pierre Graber took the opportunity to speak at length about Switzerland's place in the international system. In front of the Swiss National Council, Graber agreed that, since the October 1973 Arab-Israeli War, international relations, and particularly North-South relations, had changed. At a time when Third World leaders were trying to force the reorganisation of the international order, he insisted that Switzerland could not remain iso-

100 Interpellation by National Councillor Walther Hofer on 13 December 1974, "Interpellation Hofer-Bern. Internationale Lage - Situation internationale”, Amtliches Bulletin der Bundesversammlung 1975, Sommersession Nationalrat, 16.06.1975, pp. 842-849, p. 842; Peter Stettler, "Walther Hofer", 11.03.2014, HLS Online. 
lated. The economic interdependence of developing and industrialised states required Bern to participate actively in multilateral negotiations: "[t]he game being played is global; no one can avoid it." In order to improve its image and defend its political and economic interests, Graber asserted that the Swiss government needed to strengthen its relations with Third World states. ${ }^{101}$

The decolonisation of Angola and Mozambique occurred at a time when both North-South relations and Switzerland's foreign policy underwent a period of change. The 1973 oil shock, Third World demands for a NIEO, the assertive behaviour of Afro-Asian states at the 1974 ICRC IHL conference and other international organisations, OAU threats to blacklist firms trading with Rhodesia, and the scandal over the Ethiopian Emperor's Swiss bank accounts all contributed to a growing realisation that Switzerland's position in NorthSouth relations needed a rethink. By mid-1975, FPD leaders recognised the need to extend their efforts to lead a more active foreign policy on the Third World. When it came to East-West relations in Europe, similar steps had already been taken. At the CSCE negotiations in Geneva between September 1973 and July 1975, the Swiss delegation played an unusually energetic role, which led historian Thomas Fischer to talk about a "successful activation" of Switzerland's foreign policy in this sphere of international relations. ${ }^{102}$ Western observers highlighted the possibility of a positive Swiss contribution to the relaxation in East-West relations:

Switzerland may be small in the scheme of things and may still cling to her neutrality. But she is politically and socially one of the stablest countries in Europe, with a strong regard for liberty and a firmly democratic system of government [...]. She is an important trading partner with one of the highest standards of living and one of the strongest currencies in the world; financially Switzerland is in many ways a major Power. She is, moreover, situated in a key position along the NATO defence line across the continent. ${ }^{103}$

101 Statement by Federal Councillor Pierre Graber, "Interpellation Hofer-Bern. Internationale Lage - Situation internationale", Amtliches Bulletin der Bundesversammlung 1975, Sommersession Nationalrat, 16.06.1975, pp. 842-849, citation p. 847; see also Fischer, Die Grenzen der Neutralität, pp. 131-132.

102 Fischer, Die Grenzen der Neutralität, p. 157.

103 Diplomatic report no 12/75 from John Richard Wraight, British ambassador in Switzerland, to the British Secretary of State, "Switzerland and Europe", 17.12.1974, p. 7, TNA FCO $33 / 2575$. 
In the Third World, Swiss foreign policymakers were more hesitant. Their policy choices in Southern Africa both contributed to and were profoundly influenced by the realisation that more openness towards developing countries was needed. Like almost no other region in the world, Southern Africa demonstrated the damage to the image of Switzerland's neutrality caused by the focus on the pursuit of economic and financial gain at the expense of equality and human rights. At the same time, the Swiss government's efforts to get on good terms with Angola's and Mozambique's potential future rulers were reinforced by the need to respect Afro-Asian leaders' demands that the independence of the former colonies should finally be supported.

Between 1974 and mid-1975, FPD leaders' attitudes towards a number of actors - whose participation in international diplomacy they had formerly viewed with distrust and attempted to minimise-slowly, hesitantly, started to shift. These included non-state actors, such as liberation movements, and organisations such as the NAM. As late as 1973, Swiss foreign policymakers were wary of these new actors that challenged the rules of international relations. After the fourth NAM summit in Algiers in September 1973, Michael Gelzer, deputy chief of the DPA, still insisted on the need for Switzerland to keep its distance from the "wasps' nest", as he disparagingly labelled the NAM. This distrust was not only due to the political and economic demands of Third World leaders that 'politicised' non-political organisations and conferences; Swiss political leaders also wanted to clearly distinguish Switzerland's neutrality from other forms of non-alignment, fearing that the image of the former might suffer if the country was too closely associated with the NAM. ${ }^{104}$ This last point explains why the Swiss government not only did not participate but even actively avoided being invited to the NAM summit in Algiers, even though neutral Sweden, Austria, and Finland attended as observers. ${ }^{105}$

However, FPD leaders soon realised that the Third World political movements' demands could not be ignored. At a meeting of the Foreign Policy Committee of the National Council in mid-April 1974, Pierre Graber insisted that the demands for fair commodity prices were "difficult to contest". He sought to reassure the foreign policy specialists that, despite radical rhetoric that was mainly destined for their own citizens, most non-aligned governments

104 Letter from Michael Gelzer to the Swiss embassy in Kenya, 14.09.1973, SFA E20o1E-o1\#1987/ 78\#706*.

105 Pierre Luciri, DPA, memorandum, "Conférence au sommet des non-alignés (Alger, septembre 1973). Présence de l'Autriche, de la Suède et de la Finlande. Absence de la Suisse", 19.08.1975, attached to the note from Jürg Andreas Iselin to the head of the FPD, "La Suisse et les non-alignés", 20.08.1975, SFA E2001E-o1\#1987/78\#706*. 
pursued a "reasonable, nuanced" foreign policy. ${ }^{106}$ In late October 1974, a slight softening can be observed in Switzerland's position with regard to the participation of African liberation movements and the PLO in international organisations. Franz Muheim, chief of the DIO's section for the UN and international organisations, remained opposed to the full admission of these movements, which would constitute their de facto recognition as legitimate international actors, and wanted Swiss delegations to continue abstaining from such votes. He suggested, however, that they should use their right to explain Switzerland's position. This would lessen Switzerland's political distance from other small European states, like Sweden and the Netherlands, that had frequently voted in favour of the liberation movements' participation. ${ }^{107}$

In a position paper written in February 1975, members of the DPA and the DIo explicitly linked the Swiss government's policy on decolonisation and white minority rule with Afro-Asian states' condemnation of the 'neo-colonialist' activities of Western powers and the role of foreign investments and multinational firms in the pillaging of the Third World's resources. ${ }^{108}$ This position paper is the first time that FPD leaders spelled out Switzerland's long-standing policy on decolonisation: "In accordance with its policy of neutrality and, consequently, the principle of non-interference in the internal affairs of other states, Switzerland abstains from interfering in any decolonisation process as a matter of principle." 109 That they did so at a time when the problem of decolonisation was, with a few exceptions, restricted to Southern Africa testifies to the growing pressure that the Swiss government faced from the Third World political movement. With an economy strongly oriented towards foreign markets, Swiss policymakers felt particularly threatened by, and were sensitive to, Third World criticism. Thus, they were anxious to make use of opportunities to improve political relations with Afro-Asian states in order to protect economic interests. Yet, the paper highlights Bern's unwillingness to change its position on white minority rule in Southern Africa. Focusing on a selective interpretation of neutrality, the authors explained their restrained policy on South Africa, Rhodesia, and Namibia. As the decolonisation of Portuguese Africa was well

106 Pierre Graber's speech at the meeting of the Foreign Policy Committee of the National Council on 24 April 1974, "Tour d'horizon", no date, p. 17, SFA E1050.12\#1995/512\#8*.

107 Note from Franz Muheim, chief of the DIo's section for the UN and international organisations, to René Keller "OLP - Afrikanische Befreiungsbewegungen; Stellung der Schweiz", 29.10.1974, pp. 3-4, SFA E2003A\#1988/15\#573*.

108 Claude Huguenin, DPA; Armin Kamer, Franz Muheim, Marianne von Grünigen, DIo, memorandum, "Note sur la décolonisation. (Aspects multilatéraux et bilateraux intéressant la Suisse)", 28.02.1975, pp. 3-4, SFA E2003A\#1988/15\#573*.

Ibid., p. 9 . 
under way, they underlined their willingness to grant humanitarian aid to and establish contact with the future governments of Angola and Mozambique. Nevertheless, in July 1975, Switzerland was explicitly mentioned in a resolution by the OAU Council of Ministers that urged "the Western Powers, particularly the United States of America, Great Britain, France, the Federal Republic of Germany, Switzerland and Japan to end immediately all cooperation with the regimes in Pretoria and Salisbury".110

In mid-1975, the increasing polarisation in North-South relations led to a reconsideration of Switzerland's relations with the NAM. The issue was raised by Pierre Luciri, a young diplomatic officer at the DPA's African, Asian, Middle Eastern and Latin American Division who would obtain his $\mathrm{PhD}$ in political science at the Graduate Institute of International and Development Studies in 1976 for a thesis on Swiss foreign policy during the First World War. In a note to his supervisor in late May 1975, Luciri suggested that Switzerland seek to participate at NAM meetings as an observer. This would allow Bern to be rapidly informed of the evolution of this political force, win sympathies, and neutralise criticism. Luciri argued that, as Switzerland had been a founding member of the OECD's International Energy Agency (IEA) in November 1974, observer status at the NAM was consistent with Switzerland's neutrality:

As soon as our material interests are concerned, our neutrality scruples hardly count any more. In contrast, it is traditionally more difficult for us to discern our immaterial interests and to seek to evoke sympathies if the game does not appear to be commercially or financially profitable. Thereby, we identify ourselves more and more with the group of rich countries at the OECD. ${ }^{111}$

Although FPD leaders decided that it would be precipitate to send a representative to the NAM's conference of foreign ministers in Lima in late August 1975, many of them shared Luciri's opinion. "If neutrality allows us to participate fully in the politics of the rich countries, it will also allow us to simply go and

110 Resolution CM/Res 422 (XXV) of the OAU Council of Ministers' $25^{\text {th }}$ Ordinary Session from 18 to 25 July 1975, "Resolution on Sanctions against the White Minority Regimes in Southern Africa", https://au.int/sites/default/files/decisions/9588-council_en_18_25_july_1975 _council_ministers_twenty_fifth_ordinary_session.pdf (13 January 2021).

111 Note from Pierre Luciri to Jürg Andreas Iselin, "La Suisse et les non-alignés", 28.05.1975, p. 2, SFA E2001E-o1\#1987/78\#706*.On Luciri, see Jacques Rial, Le bicorne et la plume. Les publications de diplomates suisses de 1848 à nos jours. Un essai de bibliographie, Malta and Geneva: DiploFoundation, Graduate Institute of International and Development Studies, 2008, pp. 156-157. 
listen to the debates of the poorer countries", Jürg Andreas Iselin, deputy chief of DPA and chief of its African, Asian, Middle Eastern and Latin American Division, argued in a note to Pierre Graber, demanding his boss' authorisation to pursue a rapprochement with the NAM. ${ }^{112}$ This realisation would bear fruit the following year, and Switzerland would, for the first time, be present at an NAM summit.

Despite Bern's growing openness towards liberation movements and the NAM and its participation in the North-South dialogue, policy changes remained restricted to the diplomatic level. Pierre Graber and some of his team's attempts to strengthen Switzerland's relations with the Third World faced domestic opposition. This was particularly visible in the debates of the Advisory Commission on Switzerland's Relations with the UN. This commission was created in August 1973 to discuss Switzerland's accession to the world organisation and included representatives of the Swiss parliament, political parties, universities, trade associations, labour unions, legal experts, and the press. The polarisation in North-South relations, and the Arab states' attempt to isolate Israel and the 1974 UNGA decision to withhold South Africa's voting rights, in particular, increased scepticism of the UN. Although the commission's final report in May 1975 recommended that Switzerland join the UN, an important minority rejected it. ${ }^{113}$ While the Trade Division agreed to a rapprochement with the NAM in order to gain a source of information about the North-South dialogue, Jürg Andreas Iselin admitted in August 1975 that the FPD could not readily count on the Swiss people's support for this step. ${ }^{114}$ In the face of this resistance to a more active Third World policy and the escalation of the Angolan War, Swiss foreign policymakers concentrated on the establishment of cordial political relations with independent Mozambique.

112 Note from Jürg Andreas Iselin to the head of the FPD, "La Suisse et les non-alignés", 20.08.1975, p. 2, SFA E2001E-01\#1987/78\#706*.

113 Fischer, Die Grenzen der Neutralität, pp. 158-186.

114 Note from Jürg Andreas Iselin to the head of the FPD, "La Suisse et les non-alignés", 20.08.1975, p. 2, SFA E2OO1E-01\#1987/78\#706*. 